\title{
Tool-use experiments to determine the function of an incised ground stone artefact with potential symbolic significance
}

\author{
Elspeth Hayes ${ }^{1}$, Caroline Spry ${ }^{2,3}$, Richard Fullagar ${ }^{1}$, Anna Tuechler ${ }^{4}$, \\ Petra Schell ${ }^{2}$, Megan Goulding ${ }^{2}$
}

1. Centre for Archaeological Science, University of Wollongong, Northfields Avenue, Wollongong, NSW, 2522, Australia. Email: Hayes: ehayes@uow.edu.au; Fullagar: fullagar@uow.edu.au

2. Ochre imprints, P.O. Box 280, Clifton Hill, Vic. 3068, Australia.

Email: Spry: caroline@ochreimprints.com.au; Schell: petra@ochreimprints.com.au;

Goulding: meg@ochreimprints.com.au

3. Department of Archaeology and History, La Trobe University, Bundoora, Vic. 3086, Australia

4. Aboriginal Victoria, Department of Premier and Cabinet, Level 3, 1 Treasury Place, East Melbourne, Vic. 3003, Australia. Email: Tuechler: aktuechler@gmail.com

\begin{abstract}
:
Ground stone implements are found across most Australian landscapes and are often regarded as Aboriginal tools that were used for processing or modifying other items such as plant foods, plant fibres, resins, bone points, pigments and ground-stone axes and knives. Less common are ground stones modified for non-utilitarian, symbolic purposes; for example, polished and carved stone ornaments; ritual implements such as cylcons and tjuringa sacred stones; and unused, well-crafted ground-stone axes. In this paper, we report on the function and potential significance of an unusual ground stone artefact from a site near Bannockburn, southwestern Australia. A set of regularly spaced, shallow grooves has been cut into the surface of each side of the stone. Use-wear, residues and experimental replica tools indicate that the grooves were probably made with a stone flake and then used to shape or sharpen wooden implements such as spear points or the edges of boomerangs or other weapons. The microscopic wear outside the grooves indicates contact with soft wood or other plant material, possibly a soft plant fibre bag. We suggest that the Bannockburn artefact primarily functioned as a woodworking tool, but the even spacing of the incisions suggests that they were intentionally placed, perhaps to convey a special meaning, perhaps as a tally system or other form of communication.
\end{abstract}

Keywords: microwear; use-wear; residues; incised stone; southwestern Australia; Holocene; stone tool technology; ground stone

\section{Introduction}

Aboriginal stone artefacts of symbolic, artistic and cultural significance are recognised throughout Australia, attesting that many stones have meaning beyond a simple utilitarian

Published by the School of History, Classics and Archaeology, University of Edinburgh ISSN: 2055-0472. URL: http://journals.ed.ac.uk/lithicstudies/

Except where otherwise noted, this work is licensed under a CC BY 4.0 licence. 
purpose (see Taçon 1991). Engraved or deliberately incised stones may function as abrading or filing stones but also as symbolic items with clearly defined imagery. Brumm et al. (2006) provide a global review of stones with engraved or incised lines that have been interpreted as items of functional or symbolic significance. Utilitarian tools with incised lines from Australia include morah stones, which are large flat grinding stone slabs with deeply incised, parallel lines for processing toxic nuts in northeastern Queensland rainforests; and "bone shaping stones”, known mostly from the east coast and south-eastern Australia and used to make bone points (McCarthy 1976). McCarthy (1976) illustrates a range of incised stones. Dr. Dan Witter (personal communication with Dan Witter in November 2015) documented a calcarenite specimen in southwestern Victoria in the late 1970s, and interpreted its likely function was to grind small bone points. Towle (1944) reported an incised sandstone slab from coastal New South Wales and suggested that it may have been used for sharpening the points of spears.

In this paper, we describe a ground stone artefact, identified during an archaeological salvage program undertaken in Bannockburn, southwestern Victoria (Spry et al. 2019; Tuechler \& Spry 2015) (Figure 1). The artefact is an abrasively smoothed, tabular fragment of sandstone with 14 evenly spaced grooves (eight on one side and six on the other). Our aim is to determine how the artefact may have been used and to evaluate the potential significance of the grooves. The life history of this artefact and interpretations of its possible function and significance were reconstructed from use-wear and residue analyses, comparisons with experimental replica tools and records of incised stones in archaeological and museum collections. This project has been undertaken in collaboration with the Wathaurung Aboriginal Corporation (WAC). WAC represents members of the Wadawurrung, the Traditional Owners of central southwestern Victoria.

\section{Bannockburn archaeological salvage program}

The Bannockburn archaeological salvage program was carried out in compliance with an approved Cultural Heritage Management Plan, prepared ahead of stormwater drainage works associated with a recently constructed subdivision (Light \& Tuechler 2014). The works area was located on Bruce Creek, which forms the interface between sedimentary plains to the west and basalt plains to the east. Bruce Creek dissected these plains during the Holocene, resulting in the exposure of underlying Oligocene limestone and marl and the accretion of alluvial silts (Robinson et al. 2003).

Numerous cultural resource management studies have been undertaken in the Bannockburn area, and have identified surface and subsurface stone artefacts as a common occurrence in the Bruce Creek corridor (e.g., Clark 2010; Hyett \& Marshall 2007; Marshall \& Paynter 2003; Tuechler \& Spry 2016). Based on these data, Tuechler \& Spry (2016: 44-45) determined that the area was a focus of Aboriginal occupation and related activities, including (1) the production and use of stone tools (both ground and flaked) and (2) the fashioning and curation of wooden implements. The presence of ochre at two Aboriginal sites may indicate the use of pigment either in ceremonies or for activities such as animal skin processing (e.g., Dickson 1981; Griffin et al. 2013). 


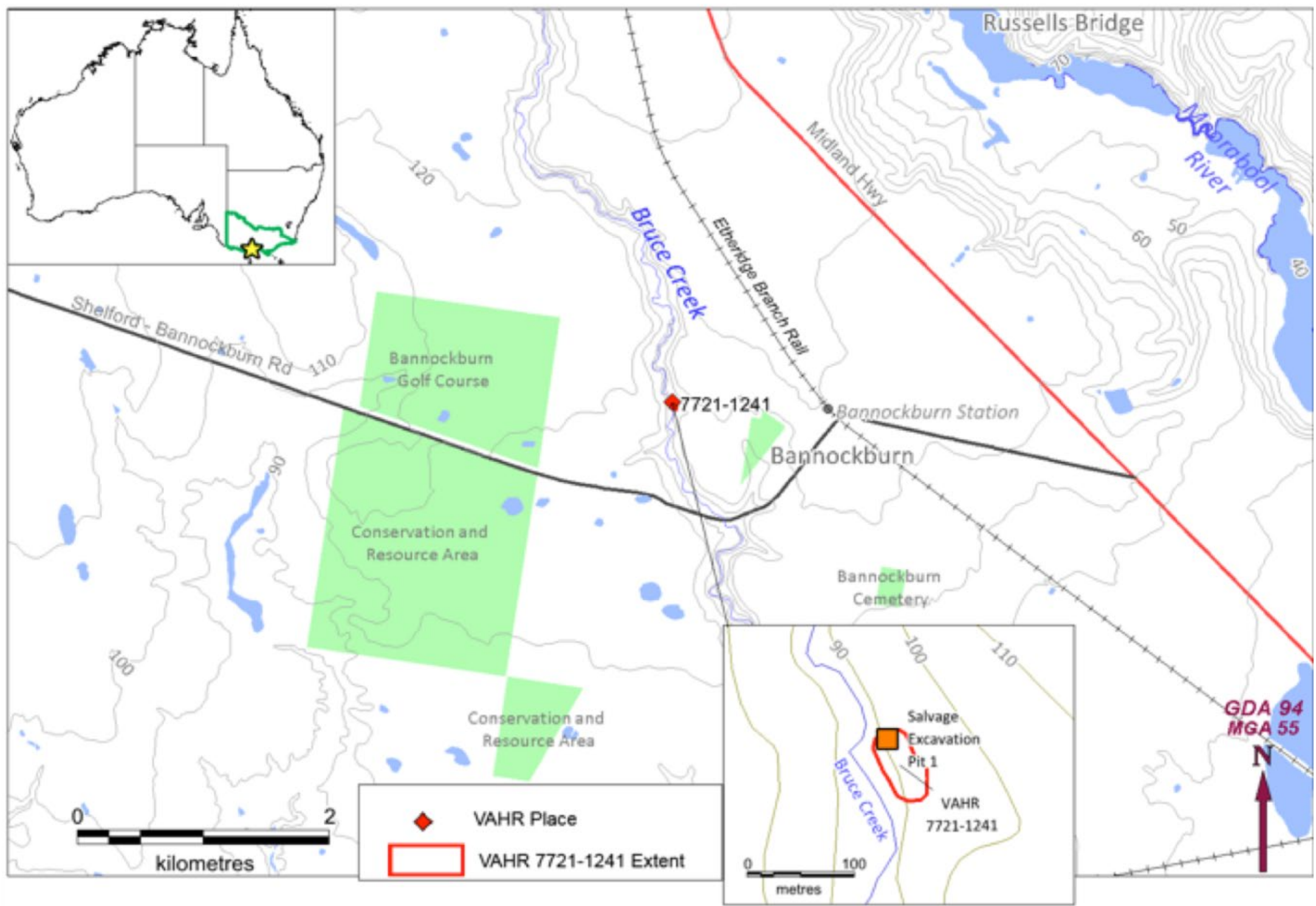

Figure 1. Site location showing Salvage Excavation Pit 1 (SEP1), site VAHR 7721-1241 and Bannockburn. 
The ground stone artefact GS491 that is the subject of this paper was identified in floodplain deposits on the eastern side of Bruce Creek, where an artefact scatter is registered with Aboriginal Victoria as VAHR 7721-1241. This Aboriginal site was documented initially by Light and Tuechler (2014: 94-95, 100), at which time 65 flaked stone artefacts made on quartz $(n=26 ; 40 \%)$, quartzite $(n=22 ; 34 \%)$, microcrystalline silcrete $(n=15 ; 23 \%)$ and fine-grained silcrete $(\mathrm{n}=2 ; 3 \%)$ were identified. The artefacts occurred in alluvial silts to a depth of $540 \mathrm{~mm}$ below the surface and across an area of 2,167 $\mathrm{m}^{2}$ (i.e., the extent of VAHR 7721-1241). Based on subsurface testing carried out at the time, the site VAHR 7721-1241 was estimated as having an average subsurface stone artefact frequency of 16.07 artefacts per cubic metre (by volume) and 10 artefacts per square metre (by area, Table1).

Table 1: VAHR 7721-1241 Artefact density (based on subsurface testing undertaken by Light \& Tuechler (2014) and Tuechler \& Spry (2015)).

\begin{tabular}{|c|c|c|c|c|c|}
\hline Stage of investigation & $\begin{array}{l}\text { Excavated } \\
\text { Sediment } \\
\text { Volume }\left(\mathrm{m}^{3}\right)\end{array}$ & $\begin{array}{l}\text { Excavated } \\
\text { Area }\left(\mathrm{m}^{2}\right)\end{array}$ & $\begin{array}{l}\text { No. of } \\
\text { Artefacts }\end{array}$ & $\begin{array}{l}\text { Average no. } \\
\text { of Artefacts } \\
\text { per } \mathrm{m}^{2}\end{array}$ & $\begin{array}{l}\text { Average no. } \\
\text { of Artefacts } \\
\text { per } \mathrm{m}^{3}\end{array}$ \\
\hline CHMP & 4.045 & 6.50 & 65 & 10 & 16.069 \\
\hline $\begin{array}{l}\text { Salvage program - } \\
\text { manual excavation }\end{array}$ & 5.200 & 8.00 & 179 & 22.375 & 34.423 \\
\hline $\begin{array}{l}\text { Salvage program - } \\
\text { mechanical stripping } \\
\text { plus monitoring }\end{array}$ & not applicable & 2152.50 & 560 & 0.260 & $\begin{array}{l}\text { not } \\
\text { applicable }\end{array}$ \\
\hline Total & 9.245 & 2167.00 & 804 & 32.635 & 50.492 \\
\hline
\end{tabular}

Eight square metres of the site VAHR 7721-1241 were excavated by hand and the remainder of the site was excavated by mechanical stripping and monitored to recover artefacts. Soils from hand and machine excavation were sieved through $5 \mathrm{~mm}$ mesh in order to recover artefacts. The manual excavation recovered on average 22.38 stone artefacts per square metre ( $\mathrm{n}=179 ; 24 \%)$. The ground stone artefact (GS491) was recovered from Layer 1 , Spit 2, Quadrant A of Salvage Excavation Pit 1 (SEP1) - one of two 2 x 2 m pits excavated manually at VAHR 7721-1241 (Figure 2). SEP1 was excavated in $100 \mathrm{~mm}$ spits until a culturally sterile, mottled black and orange clay was encountered at a depth of $580 \mathrm{~mm}$ below surface. The overlying floodplain sediments comprise brown, dry and weak-friable silt, 0-440 mm below surface (Layer 1); and a brown, dry and friable-cemented silt, $440-580 \mathrm{~mm}$ below surface (Layer 2). Minor evidence for bioturbation in both layers includes insects, grass rootlets and small tree roots. However, the presence of refitted sets of flaked stone artefacts, together with several groups of artefacts whose visual characteristics (e.g., colour, texture, cortex, inclusions) suggest each group was struck from the same core or tool, indicate that these sediments are reasonably intact and not greatly disturbed (Tuechler \& Spry 2015:10-15, 25). While no age estimates are available for the excavated alluvial silts, or the materials they encase, previous studies indicate that these silts were deposited during the Holocene (Robinson et al. 2003).

In total, 739 stone artefacts were retrieved from site VAHR 7721-1241 during the salvage program, bringing the total number of artefacts identified at this site to 804 (supplementary data: Table 2: Proportions of different artefact and tool types identified at site VAHR 7721-1241 during the CHMP and salvage investigations). A large proportion of the salvaged artefacts $(n=560 ; 76 \%)$ were identified during monitoring and mechanical stripping of sediments. Quartz is the most common material in the salvage assemblage ( $\mathrm{n}=341 ; 46 \%)$, followed by silcrete $(n=332 ; 45 \%)$, quartzite $(n=46 ; 6 \%)$, sandstone $(n=9 ; 1 \%)$, crystal quartz $(\mathrm{n}=2 ;<1 \%)$ and other raw materials $(\mathrm{n}=4 ;<1 \%)$. None of the ochre has macroscopic 
evidence of surface modification, such as grinding marks, and it is not possible to determine whether any ochre was intended for symbolic or utilitarian purposes. Of the flaked stone artefacts, silcrete and quartz appear to have been treated differently. The silcrete was transported to the activity area in a smaller or more prepared form (compared with quartz), and worked more heavily to produce a range of informal and formal tools that include notched artefacts, utilised flakes, backed artefacts and a variety of scrapers. In contrast, the quartz was brought to the site as unworked pebbles or cobbles and reduced less heavily (compared with silcrete), and occasionally on an anvil, to only produce informal tools (Light \& Tuechler 2014:99-111; Tuechler \& Spry 2015: 22-38).
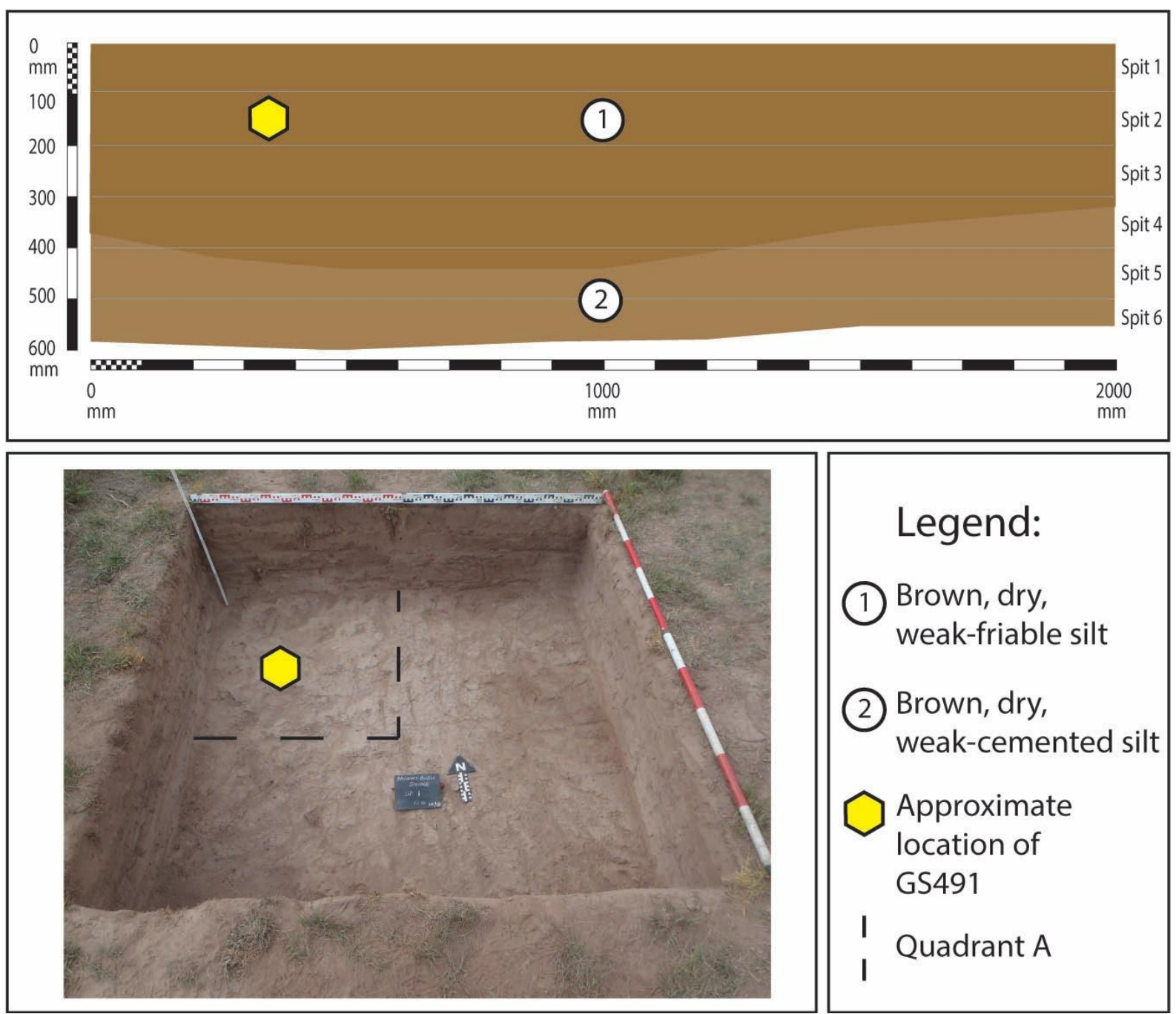

Figure 2. Upper, Stratigraphic profile of Salvage Excavation Pit 1. Lower, Base of Salvage Excavation Pit.

\section{Artefact description}

GS491 comprises two sandstone fragments (broken prior to excavation), that refit to make a complete but small ground stone artefact with distinctive macroscopic features, including rounded margins, extensively smoothed surfaces and 14 incised grooves, six on Surface 1 and eight on Surface 2 (Figure 3). Microscopically, all surfaces of the tool appear to have been abrasively smoothed to some degree, probably to shape the tool into a desired form. The stone is a weakly cemented, relatively soft sandstone - the type of material that is easy to work and typically very effective at sharpening and filing implements made of stone, bone or wood (Hayes 2015). Four of the near parallel grooves on Surface 1 and five of the 
near parallel grooves on Surface 2 are similar in length, width and depth, although they appear to be slightly deeper on Surface 1 . The grooves are oriented differently on each of the Surfaces and, on Surface 1, two macroscopically visible grooves are shorter and oriented differently from other grooves on that side.
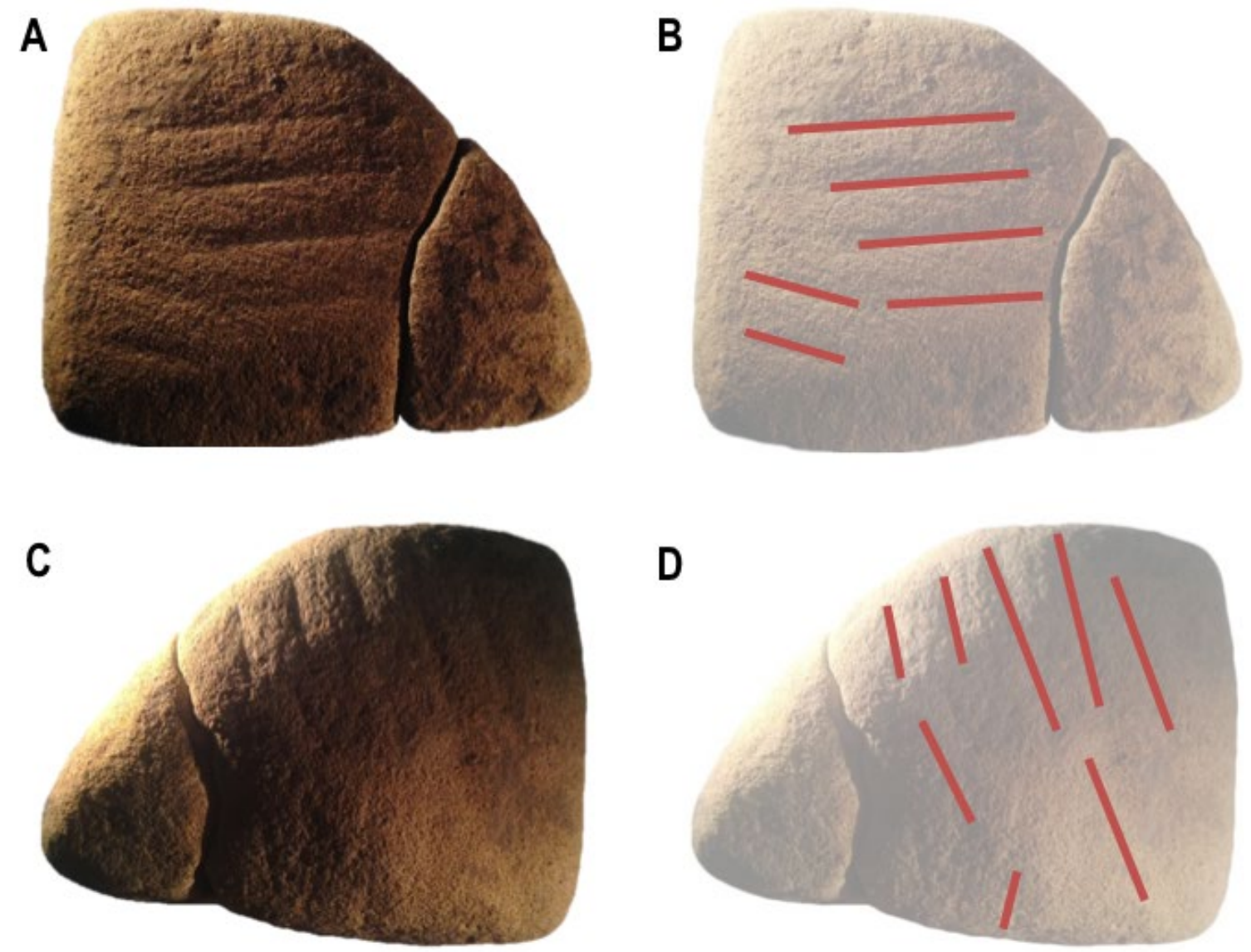

Figure 3. Grinding stone specimen 491 with distinctive grinding wear, including areas of abrasion and macroscopically visible grooves. A-B) Surface 1: note the four parallel grooves running perpendicular to the fresh break; C-D) Surface 2: note the five parallel grooves running parallel to the fresh break. Scale bar is $5 \mathrm{~cm}$.

\section{Experimental replica tools}

To determine how the grooves were made on grinding stone GS491, we analysed usewear and residues and compared our findings to two experimentally ground replica tools incised with three different materials: stone, wood and bone. Both experimental tools were made of soft, weakly cemented sandstone that was similar to GS491 in composition (e.g., grain size and nature of cementing matrix). The experimental sandstone pieces were shaped by hard hammer percussion and then abrasively smoothed on all surfaces, using a harder sandstone grinding slab (Figure 4A-C) Grooves were made on each surface of both stones and their length, width, depth and position were made to replicate the grooves on GS491 (Figure $4 \mathrm{D}-\mathrm{F})$. On the first sandstone piece, Tool 1, Surface 1 grooves were created with a bone point made from macropod fibula (Figure 4D). Grooves on Surface 2 on Tool 1 were made with a flint flake (edge angle $25^{\circ}$, Figure 4E). On Tool 2, Surface 1 grooves were created using a retouched flint flake (edge angle $80^{\circ}$, Figure 4F). Grooves on Surface 2 of Tool 2 were created using dry wood (Eucalyptus leucoxylon). We selected yellow gum for our wood 
experiments because it grows locally in southwestern Victoria and it was selected by Aboriginal people to make wooden implements in the recent past (Kamminga 2002). Quartz (which is common stone material found at the site occurring as both artefacts and unmodified stones) would have been just as effective as flint and has similar hardness (MOHS scale: 7). Flint was used here because of our supplies and its more predictable flaking properties.
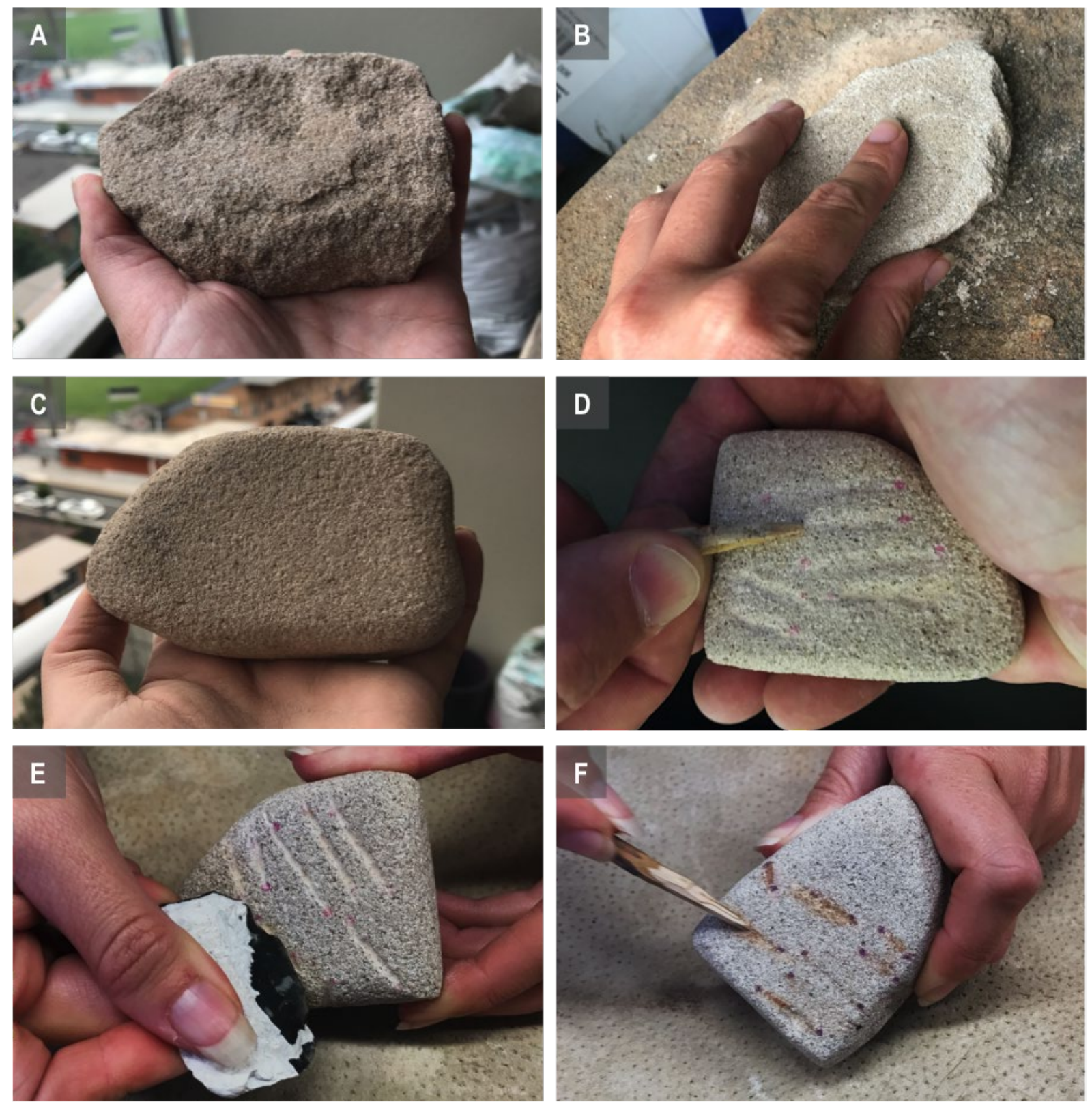

Figure 4. Making of the experimental sandstone replica tools: A) a weakly cemented, soft sandstone fragment shaped to resemble GS491; B) abrasively smoothing the surface of Experimental Tool 1 using a harder sandstone grinding slab; C) abrasively smoothed sandstone blank before incisions; D) Tool 1, Surface 1 grooves being created with a macropod fibula bone; E) Tool 1, Surface 2 grooves were made with the edge of an acute angled stone flake made from South Australian flint; F) Tool 2, Surface 2 grooves created using dry wood (Eucalyptus leucoxylon).

\section{Residue and use-wear analyses}

Examination of GS491 and experimental tools involved several microscopes and lighting arrangements. Low magnification observations (x6.7 to x45) were undertaken with an Olympus SZ61 stereozoom microscope with an external fibre optic 150 Watt halogen light 
source (Olympus LG-PS2) and a Leica MZ16A stereozoom microscope with an automatic Zstacking function. Multifocal images were obtained with a DFC320 Leica camera and stacked to create a focused image using Leica LAS V4.4 software. Higher magnification observations were undertaken with an Olympus metallographic microscope (model BH-2) with vertical incident light (brightfield and darkfield) with objective lenses of x50, x100, x200, and x500 and polarising filters. Micrographs of wear traces were captured with an Olympus Infinity 2 digital camera and stored as TIF files.

Neither GS491 nor the experimental tool was washed prior to analysis, and handling of GS491 was minimised after it was identified during excavation. The archaeological tool had a fine layer of sediment that obscured the surface. Observations of wear and residue traces were made directly on the artefact surface prior to residue removal and again after removal (which allowed some areas of the artefact to be cleaned). Removed material was also examined at high magnification in transmitted light.

Residue samples were extracted with distilled water using an adjustable pipette on both the archaeological and experimental tools. Samples were extracted from eight locations on the tool surface of GS491. Four residue samples from the experimental artefacts were analysed, including one sample from each of the grooves made with wood and bone. The two other residue samples were extracted from outside the grooves and adjacent to where the bone and wood residue samples were recovered and were intended to be controls. Residue samples were not extracted from grooves incised with flint as only mineral residues were expected.

The same method for residue extraction was applied to both the experimental and archaeological tools. Up to $100 \mu \mathrm{l}$ of water was delivered by pipette to the sampled area, either along the entire length of each groove, or $<1 \mathrm{~cm}^{2}$ for controls away from the grooves. The solution was lightly agitated with a pipette tip to dislodge firmly adhering residues and drawn back into the pipette. Approximately 5-15 $\mu$ l of extracted sample was delivered on to a clean glass slide (wiped with acetone), covered with a clean glass cover slip that was sealed with clear nail varnish in each corner. The edges of the cover slip remained unsealed so that water, stains and other solvents could be added as required.

Methylene Blue $\left(\mathrm{C}_{16} \mathrm{H}_{18} \mathrm{~N}_{3} \mathrm{SCI}\right)$ was applied to all eight residue extractions to distinguish any highly degraded, damaged or morphologically indistinct plant tissues. Methylene Blue is a water soluble dye that binds to the acidic pectins on the cellulose cell wall that are stained various shades of blue (Lillie 1976: 425; Stadelmann \& Kinzel 1972). The colour and intensity of the stained cellulose fibres are related to the purity of cellulose (the darker the blue, the more pure). Up to $5 \mu$ of Methylene Blue were added to the residue slides and left for at least 20 minutes to allow the stain to be absorbed. Excess stain was rinsed (by washing water through the slide), and the slide was examined again in transmitted light.

\section{Results}

\subsection{Use-wear}

\subsubsection{Experimental tools}

The experimental sandstone replica tools were easily shaped and smoothed (within 15 minutes) by hard sandstone; and the flint flakes rapidly incised each groove (within 2 minutes). The grooves made with the acute stone edge appeared to be sharper and narrower than the grooves made with the steep angled retouched edge (Figure 5M). Under high magnification, the grooves made with stone displayed abundant micro-fracturing of quartz grains but little or no polish development (Figure 50). The grooves made with wood and bone were much harder to create because both materials are softer than the sandstone, and shallow grooves only formed after 5-15 minutes, respectively. Macroscopically and at low 
magnification, the grooves made with both the wood and bone were distinctly more shallow, broader and not as straight than the grooves made with flint (Figure 5G,J). At high magnification, weakly polished surfaces could be distinguished within each of the grooves made by bone and wood, but owing to the short processing times, the use-polish was at early stages of formation and not diagnostic of a particular worked material. Nevertheless, in the grooves made with wood, the polish displayed an even, grainy texture with some connectivity but only in a very early stage of the reticular (net-like) wear pattern typical of woodworking (Figure 5GH). Some quartz grains had been sheared and had fresh fracture surfaces. Polish in the grooves made with bone also had a grainy texture with some patches of more developed polish and directionality (alignments of polish and striations) but was not diagnostic of a particular worked material (Figure 5K).

\subsubsection{Archaeological tool}

GS491 displayed very distinctive macroscopic and microscopic wear. The entire tool surface has been smoothed and at least 14 incised, mostly parallel grooves are visible on the two main stone surfaces. At low magnification, individual grains appear minimally levelled and highly rounded with frequent grain micro-fracturing (Figure 6A-B). Macroscopically and under low magnification, the grooves on GS491 are similar to those on the experimental tool surfaces that were made with the steep-angled stone edge (Figure 5A).

At higher magnifications (x100, x200 and x500), polish on GS491 can be distinguished on individual grains and can be attributed to use; and micro-scarring is frequently observed (Figure 5C-F). Figure 5C shows a quartz grain that has been freshly fractured, smoothed and subsequently polished, indicating that the polished zone is not an outcome of natural weathering of the constituent quartz grains. Overall, the use-polish observed inside and outside the grooves and all sides, is variable in morphology and texture, and probably indicates manufacturing stages, processing of multiple materials and perhaps also wear sustained from non-use agencies (e.g., storage and transport, trampling and deposition).

In the grooves, we documented a bright, well-developed reticulated use-polish commonly associated with the processing of siliceous plant material (Fullagar 1991). The use-polish documented on GS491 is much more developed than wear on our experimental tool used to process wood for a short duration, but is similar to the wear on other experimental tools (Hayes 2015; Hayes et al. 2018) made of the same sandstone used to sharpen dense mulga (Acacia sp.) wood for up to 2 hours (Figure 5I). It is likely that dense wood was used in the grooves on GS491 for durations exceeding 2 hours.

This use-polish is more extensively distributed on Surface 2 (Figure 5D-F), possibly indicating that this surface was used more intensively but for the same task. A brightly reflective polish (similar to plant working) outside of the grooves overlies patches of abrasive manufacture wear, suggesting that GS491 was also used to rub objects made of wood or other plant tissue. Perhaps the wear outside the grooves was sustained when the stone was wrapped with, or carried in a bag made of, plant material. As GS491 was identified in two pieces during excavation, and the broken surfaces are slightly rounded and weathered, it is possible that GS491 broke in such a travel bag before it was discarded. 

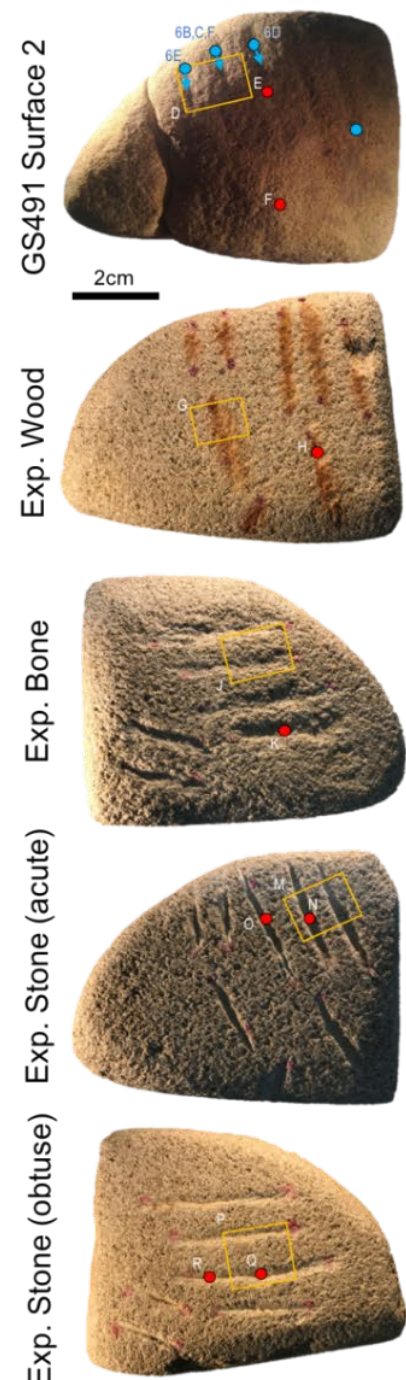
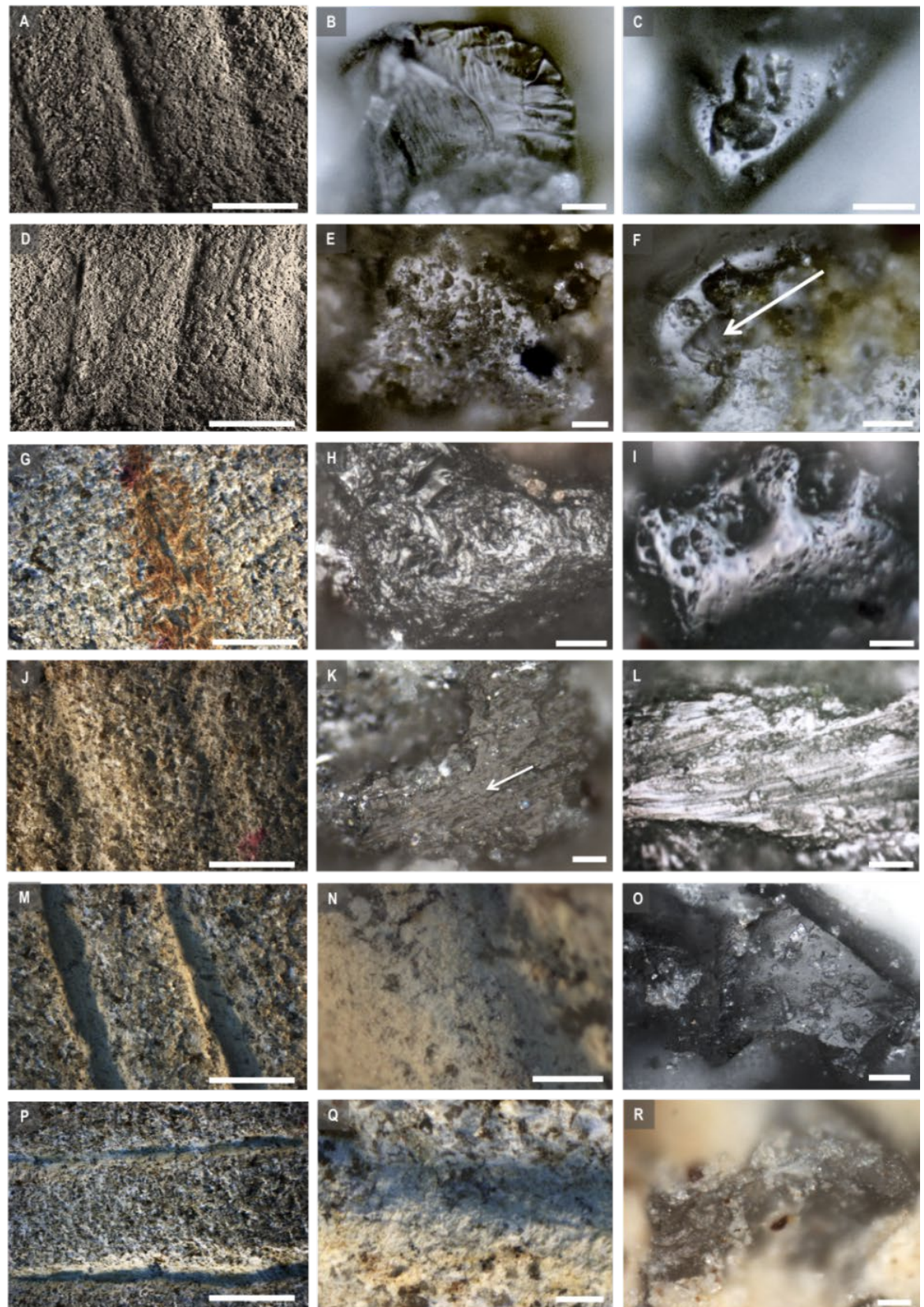

Figure 5. Use-wear documented on GS491 and experimental tools including detail of grooves and quartz grains polish, scarring and residues (indicated by red dot). A-C) Use-wear on GS491 Surface 1, note the polish and micro-scarring on quartz grain from inside the groove (B) and outside the groove (C); D-F) Use-wear on GS491 Surface 2, including micro-scarring (indicated by arrow) and a reticulated use-polish on individual grain, similar to siliceous plant processing; G-H) Use-wear on experimental tool incised with wood; polish is weakly developed showing and even, grainy texture with some connectivity but only very early stages of a reticular pattern but not diagnostic of worked material; I) Use-wear on experimental sandstone tool used for sharpening wood for 2 hours, note the developed reticulated polish; J-K) Use-wear on experimental tool incised with bone; L) Use-wear on experimental sandstone tool used for sharpening bone for 2 hours, note the striated polish; M-O) Use-wear on experimental tool incised with an acute-edged flint flake with straight grooves with a $\mathrm{V}$ cross section and fractured grains; P-R) Use-wear on experimental tool incised with obtuse-edged flake, grooves are straight and shallow with $U$ cross section. Scale bars: detail of grooves (A,D,G,J,M,P): 5mm, (N,Q) 0.5mm; micro-graphs: $20 \mu \mathrm{m}$. Residue extraction locations indicated by blue dot on tool Figures. 

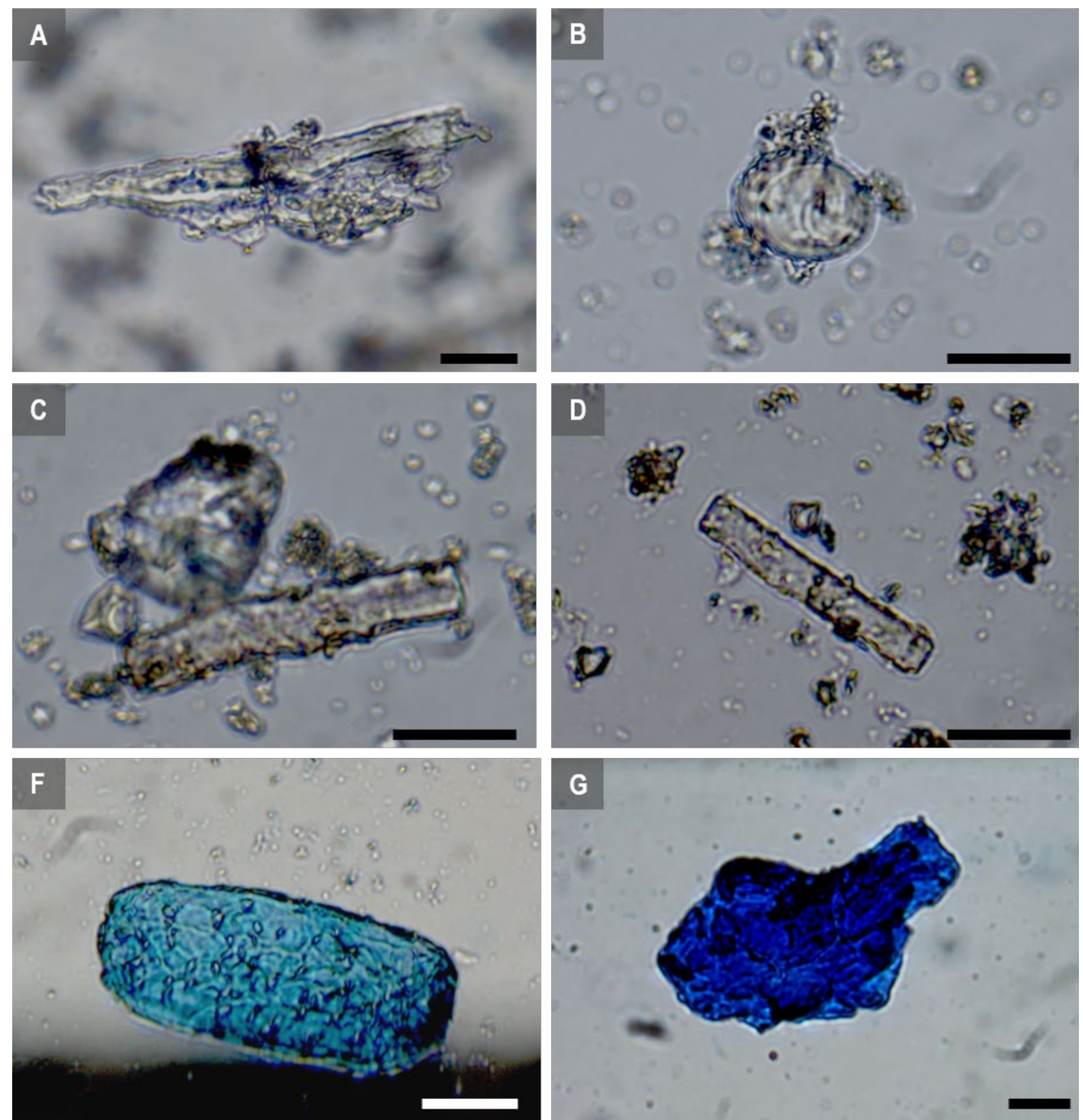

Figure 6: Residues documented on both surfaces of the tool (scale bars are $20 \mu \mathrm{m}$ ). A) amorphous tissue from a groove on Surface 1; B) isolated starch grain from a groove on Surface 2; C) degraded rod-shaped phytolith from a groove on Surface 1; D) Generic, rod-shaped phytolith from a groove on Surface. E-F) Plant tissues from grooves on Surface 2 stained with Methylene Blue.

\subsection{Residues}

\subsubsection{Experimental tools}

Not surprisingly, residues were documented in high frequency on the experimental tool that had recent contact with fresh worked materials. Wood tissue was abundant within the grooves of Experimental Tool Surface 1, and was visible macroscopically, occurring as light brown woody smears over grains and within the asperities (Figure 5G). Residue extractions from the woodworking groove contained plant particles such as cellulose and lignin, with no sign of degradation. Powdery white bone residues were documented within the grooves made on Surface 2, but these did not appear to be as tightly affixed to the stone as wood residues. The loosely adhering, powdery bone residues were easily "blown” away leaving only small 
remnant traces. Residue extractions, however, contained abundant collagen fibres that were easily identified, even without the aid of stains.

\subsubsection{Archaeological tool}

Organic residues were generally scarce on GS491. We recovered degraded plant fibres, distinctive plant structures (starch, cellulose and phytoliths) and amorphous tissue (Figure 6). Rod-shaped phytoliths (rondels) were commonly documented in extractions from Surface 2 and may originate from the sediments. Many phytoliths appeared degraded and have not been further analysed (Figure 6C-D). Only one starch grain was documented across all eight residue extractions (sampled from a groove on Surface 2), and cannot be taxonomically identified or confidently associated with use. Most of the remaining organic tissue occurred as elongated fibres, indicating a possible plant origin. Fibrous bundles, which are more typical of bone and other collagenous residues, were absent. Applications of the stain Orange G (testing for collagen) were all negative. In contrast, applications of Methylene Blue (testing for cellulose) were all positive, providing a confirmation that the degraded fibres and amorphous tissue were of plant origin (Figure 6E-F). Residue distributions outside the grooves were similar to those inside the grooves and likewise cannot be confidently be attributed to use.

\subsection{Functional Interpretation}

The grooves on GS491 are totally unlike fresh abrasions or cut marks acquired during excavations, sieving or ploughing events. Moreover, the undisturbed sedimentary context and other lines of evidence show that the incised grooves occurred prior to deposition.

(1) The grooves are individually incised, parallel and evenly spaced incisions on both sides but at different orientations, all suggesting deliberate placement.

(2) The grains within the grooves are evenly worn, suggesting that they are not recent incisions, and that they were all made at about the same time.

(3) The artefact was recovered during archaeological excavations with small trowels. The groove incisions are deeper than the likely marks made by accidental glancing blows from a trowel.

(4) The artefact was recovered from the upper $20 \mathrm{~cm}$ but in a field that has not been ploughed and we can rule out farm machinery as an agent of damage. The incisions are not all oriented in the same direction, do not always extend to the edge of the tool, and even a glancing blow from farm machinery would likely shatter the artefact into several freshly fractured pieces.

(5) We did not identify any metal residues in the incised grooves or anywhere else on the artefact surface. Metal residues are easily distinguished microscopically.

Our experiments indicate that the grooves on GS491 were first incised (most likely with a steep-edged stone flake) and subsequently used, probably to guide the path of sharp-edge wooden objects. The initial incision with stone created even, straight lines that would be impossible to achieve had the stone only been incised with wood (see Figure 5G). The usewear on incised grooves of GS491 was consistent with the use-wear on experimental tools used to work wood for durations exceeding 2 hours (see above).

The presence of polish outside of the grooves suggests that the surface has been worn perhaps from use or from contact with the inside of a plant-fibre bag. Given the nature of abrasive smoothing and the range of polish texture in and out of the grooves, it is likely that this tool was in contact with other material (apart from wood or other plant). It is also probable that tool users' hands also caused some of the wear, while the tool was being held and used. Chemical weathering or abrasion from movement or disturbance in the depositional environment was not identified. 
A parsimonious functional explanation for the artefact form, incised grooves and wear on GS491 is that a sandstone fragment was selected for its size and physical properties, and was then shaped by abrasive smoothing (probably with another piece of sandstone). Grooves were then individually incised with a stone flake. The tool was held in one hand and the incised grooves were used to guide, hold steady and sharpen and shape the margins of carved wooden objects (e.g., spear points and boomerang edges) (Figure 7). Use-wear on other parts (i.e., outside the grooves) of GS491 suggests that it was carried in a bag made of plant tissue and perhaps also used to abrasively smooth not just the edges but also the broader surfaces of the same wooden (or other) objects (e.g., spears and boomerangs, shields).

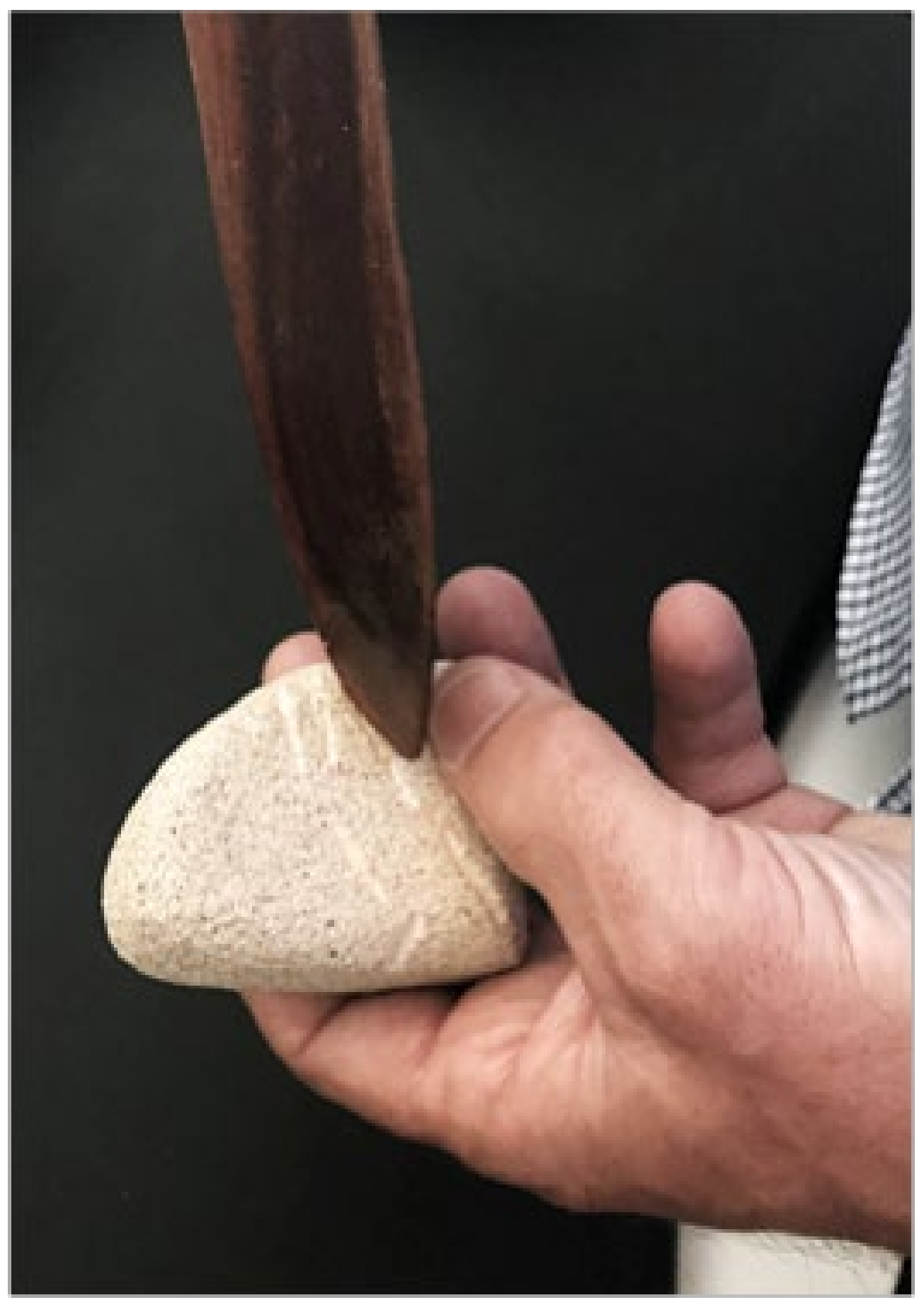

Figure 7. Using the experimental replica tool to sharpen the edge of a boomerang. 
The pattern of evenly spaced incisions on both sides of the tool is unlike the pattern of single or multiple incised grooves found on other abrading stones. Indeed, the pattern of incised grooves has more in common with carved decoration on stones or other objects thought to have ceremonial, artistic or other symbolic significance. Although we know that the grooves were functionally linked with woodworking, the pattern of incisions appears to be a deliberate design possibly to maximise use of the small sandstone tool but perhaps more likely also as a form of artistic expression or to document or convey information. We can only speculate on the nature of this information and the potential significance concerning the number of incised grooves, patterns of parallel grooves on both sides, what wooden edges and surfaces were modified, the episodes of use or whether some meaning (e.g., empowerment) was added to the tool itself, as a consequence of contact with particular wooden objects.

\section{Discussion}

Incised stones with a utilitarian purpose occur globally in the archaeological record and are generally considered to be tools used for modifying other implements, including bone points, stone axes, shell hooks and beads, wooden shafts and other polished items. Other tools with more complex incised lines are suggested to represent art, convey messages or be some form of counting or tally system.

Symbolic stones from Australia with deliberately pecked or incised motifs include cylcons and tjuringa sacred stones, which are ritual implements used for ceremonial and sorcery purposes (McCarthy 1976: 66-70; Mountford \& Walsh 1943). “Message stones” with deeply cut notches also have a symbolic function, supposedly to convey messages from their specific patterning of the incised lines, much the same as wooden message sticks (Cooper 1947). Engraved pebbles from South Australia are small, easily carried and are thought to have conveyed some sort of tally (Mountford 1960).

Portable stone engravings from dated archaeological contexts in Australia are rare. An incised limestone piece from Devil's Lair in Western Australia has an estimated age of 14 ka, and Dortch (1976: 38) suggested that the linear, geometric design could represent an attempt to convey meaning, either as self-expression or communication, and provides evidence for early symbolic behaviour (but see Bednarik 1998). Vanderwal \& Fullagar (1989) argued that 28 engraved notches on a Diprotodon tooth (with associated age estimates of 28 ka) were tally marks, perhaps to mark the lunar month (but see Langley 2020).

Although some of the incised stones possess distinctly figurative imagery that clearly identifies the artefact as one of symbolic or cultural significance, many stones with incised lines are more enigmatic. Furthermore, many functional tools also have an added symbolic or cultural value. Stone points, for example, are typically manufactured and used as spear heads for hunting and fighting weapons, but are also extremely important indicators of cultural identity, often traded in economic exchange systems and requiring delicate craftsmanship for their manufacture (Akerman et al. 2002). The role of aesthetics in lithic manufacture has been reviewed by Taçon (1991), who identified aspects of tool manufacture as forms of art. Australian ethnography has indicated that some stones with natural banding that form interesting or attractive patterns are of particular symbolic and spiritual interest, and may have been deliberately selected for knapping due to their striking appearance (Brumm et al. 2006: 184). There is sufficient evidence in Australia to suggest that many stones have a deeper, aesthetic value beyond their function. However, determining whether a stone tool may have an additional symbolic significance is speculative, although both sacred and profane contexts are possible (see Hampton 1999).

GS491 from the site near Bannockburn is enigmatic. Similar stones from around Australia with incised lines are known for processing bone awls, nose-bones, and wooden 
spear barbs; and to convey messages (McCarthy 1976: fig. 49, 57-60). Through use-wear and residue analysis and experimental replication, we have shown that this tool probably functioned as a woodworking tool, possibly for sharpening hard wooden implements such as boomerangs. However, the fact that the stone appears to have been deliberately abraded on all surfaces - perhaps to shape the tool in a certain way with one end relatively wide and the other narrower - and the pattern of evenly spaced incised grooves together imply that there was a deliberate, perhaps aesthetic or other intent. Consequently, one can speculate that this tool used for wood working also had some sort of additional symbolic function.

\section{Conclusion}

The Bannockburn ground stone tool is an enigmatic artefact that has stimulated much thought and discussion about its function and potential significance. Study of use-wear and residues on experimental tools indicates that the grooves on GS491 were probably incised with stone and were used to abrade wooden objects. Nevertheless, exactly how the artefact functioned as a tool or symbolic object remains speculative: the stone was probably used as a tool for the shaping of wooden artefacts. The pattern of incised grooves also suggests artistic expression, tally marks or other messages. On the other hand, rubbing certain wooden objects in the incised grooves may also have empowered the stone with some symbolic meaning (Hampton 1999).

Artefacts with similar incised grooves are rare and not often reported in archaeological sites, perhaps because artefacts like this have been simply overlooked during excavation and sieving. Indeed, the grooves on GS491 are subtle and could have been overlooked or interpreted as accidental markings from the ploughing, excavation tools or wire sieves. This study has emphasised the need to investigate all excavated material carefully, so as not to overlook stones with similar incisions that may shed light on the function and context of these tools.

\section{Acknowledgements}

For their support and advice during fieldwork, analysis and publication we thank the following: Wathaurung Aboriginal Corporation (Wadawurrung), Bannockburn Holdings P/L, Aboriginal Victoria, Jodi Turnbull and Katherine Thomas (Ochre Imprints), and Claire St George. The flint, used in the tool-use experiments, was collected from Nene Valley, South Australia. EH and RF thank Dan Witter for discussion about evenly spaced incised grooves and his records of a calcarenite tool with grooves for shaping bone points, which he recorded while an archaeologist with the Victoria Archaeological Survey during the early 1980s.

The authors wish to acknowledge the Wathaurung Aboriginal Corporation (Wadawurrung) as the Registered Aboriginal Party for the study area, and for giving permission to undertake this study and publish the results.

We would also like to thank the 2017 AGSTR conference organisers: Tatjana Gluhak, Stefanie Wefers and Susanne Greiff; as well as the Use-wear and Residue session chair Selina Delgado-Raack. We thank two anonymous reviewers for helpful comments on this manuscript. 


\section{References}

Akerman, K., Fullagar, A., \& van Gijn, A. 2002, Weapans and Wunan: production, function and exchange of Kimberley points. Australian Aboriginal Studies, 2002(1): 13-42.

Bednarik, R.G. 1998, Microscopic analysis of 'engraved plaques' and other objects from Devil's Lair. Journal of the Royal Society of Western Australia, 81: 165-175.

Brumm, A.R., Boivin, N., \& Fullagar, R. 2006, Signs of life: Engraved stone artefacts from Neolithic South India. Cambridge Archaeological Journal, 16(2): 165-190. doi:10.1017/s0959774306000102

Clark, N. 2010, Bruce Street Bannockburn Residential Subdivision Cultural Heritage Management Plan 10861. (Cultural Heritage Management Plan, Report No. 10861). Unpublished report for Mr Peter Carland, on file. Melbourne, 130 p.; Date: 5 October 2010.

Cooper, H.M. 1947, Incised Stones of South Australia. Mankind, 3(10): 292-298. doi:10.1111/j.1835-9310.1947.tb00120.x

Dickson, F.P. 1981, Australian Stone Hatchets: A Study in Design and Dynamics. Academic Press, Sydney, 240 p.

Dortch, C.E. 1976, Two engraved stone plaques of late Pleistocene age from Devil's Lair, Western Australia. Archaeology in Oceania, 11(1): 32-44. doi:10.1002/j.18344453.1976.tb00233.x

Fullagar, R. 1991, The role of silica in polish formation. Journal of Archaeological Science, 18: 1-24. doi:10.1016/0305-4403(91)90076-2

Griffin, D., Freedman, D.L., Nicholson Jnr, B., McConachie, F., \& Parmington, A. 2013, The Koorong Project: Experimental archaeology and Wurundjeri continuation of cultural practice. In: Excavations, Surveys and Heritage Management in Victoria, Vol. 2 (Lawrence, S., Frankel, D., Spry, C., Canning, S., \& Berelov, I., Eds), La Trobe University, Melbourne: p. 59-65.

Hampton, O.W. 1999, Culture of Stone: Sacred and Profane Uses of Stone among the Dani. Texas A\&M University Press, College Station, Texas, 331 p.

Hayes, E.H. 2015, What was ground? A functional analysis of grinding stones from Madjedbebe and Lake Mungo, Australia. PhD thesis at the Centre for Archaeological Science, University of Wollongong, Wollongong, Australia, 588 p.

Hayes, E., Pardoe, C., \& Fullagar, R. 2018, Sandstone grinding/pounding tools: Use-trace reference libraries and Australian archaeological applications. Journal of Archaeological Science: Reports, (20): 97-114. doi:10.1016/j.jasrep.2018.04.021

Hyett, J., \& Marshall, B. 2007, An Archaeological Survey at Bruce Street, Bannockburn. Unpublished report for James Ramsey, on file. Melbourne, 43 p.; Date: May 2007.

Kamminga, J. 2002, Australian Aboriginal Timber Quick Search. Document 0729, Aboriginal Studies Electronic Data Archive (ASEDA), Australian Institute of Aboriginal and Torres Strait Islander Studies.

Langley, M. 2020. Re-analysis of the “engraved” Diprotodon tooth from Spring Creek, Victoria, Australia. Archaeology in Oceania, 55(1):33-41. doi:10.1002/arco.5209 
Light, A., \& Tuechler, A. 2014, Bio-retention Basin, Bannockburn: Cultural Heritage Management Plan No. 12604. (Cultural Heritage Management Plan, Report No. 12604). Unpublished report prepared for Bannockburn Holdings P/L, on file. Melbourne, 186 p.; Date: 30 September 2014.

Lillie, R.D. 1976, H.J. Conn's Biological Stains: A Handbook on the Nature and Uses of Dyes Employed in the Biological Laboratory. Williams and Wilkins, Baltimore, 498 p.

Marshall, B., \& Paynter, N. 2003, An Archaeological Survey at Bruce Creek Bannockburn. Unpublished report prepared for Grant St Quentin Surveyors, on file. Melbourne, 53 p.; Date: December 2003.

McCarthy, F.D. 1976, Australian Aboriginal Stone Implements: Including Bone, Shell and Teeth Implements. Vol. 1 (Second ed.). The Australian Museum Trust, Sydney, 99 p.

Mountford, C.P. 1960, Unusual rock markings in Australia. Mankind, 5(9): 405-407. doi:10.1111/j.1835-9310.1960.tb00326.x

Mountford, C.P., \& Walsh, G. 1943, A stone tjurunga of unusual form from the Aranda Tribe of central Australia. Mankind, 3(4): 113-115. doi:10.1111/j.1835-9310.1943.tb00163.x

Robinson, N., Rees, D., Reynard, K., MacEwan, R., Dalhaus, P., Imhof, M., Boyle, G., \& Baxter, N. 2003, A Land Resource Assessment of the Corangamite Region (First ed.). Department of Primary Industries, Melbourne, $121 \mathrm{p}$.

Spry, C., Hayes, E., Fullagar, R., Tuechler, A., Schell P., \& Goulding, M. 2019. An unusual, incised ground stone artefact from southwestern Victoria, Australia: its function and potential symbolic significance. Australian Archaeology, 85(1): 95-101. doi:10.1080/03122417.2019.1595906

Stadelmann, E.J., \& Kinzel, H. 1972, Vital staining of plant cells. Methods in Cell Physiology, 5: 325. doi:10.1007/bf01810956

Taçon, P.S. 1991, The power of stone: Symbolic aspects of stone use and tool development in western Arnhem Land, Australia. Antiquity, 65(247): 192-207. doi:10.1017/s0003598x00079655

Towle, C.C. 1944. Small stone slab showing grooves made by the Aborigines. The Victorian Naturalist, 60: 189-190.

Tuechler, A., \& Spry, C. 2015, Archaeological Salvage Program: Bio-retention Basin, Bannockburn (Implementation of CHMP No. 12604). Unpublished report for Bannockburn Holdings P/L, on file. Melbourne, 106 p.; Date: 18 September 2015.

Tuechler, A., \& Spry, C. 2016, Somerset Estate Wetland and Drainage Basin: Cultural Heritage Management Plan No. 12362. (Cultural Heritage Management Plan, Report No. 12362). Unpublished report for Bannockburn Holdings P/L, on file. Melbourne, 165 p.; Date: 26 February 2016.

Vanderwal, R., \& Fullagar, R. 1989, Engraved Diprotodon tooth from the Spring Creek locality, Victoria. Archaeology in Oceania, 24: 13-16. doi:10.1002/j.18344453.1989.tb00201.x 